Małgorzata Bielicka

Uniwersytet im. Adama Mickiewicza

\title{
KOMPETENCJE NAUCZYCIELA JĘZYKA OBCEGO W PRZEDSZKOLU IMMERSYJNYM. PRZYGOTOWANIE STUDENTÓW KIERUNKÓW NEOFILOLOGICZNYCH DO WYKONYWANIA ZAWODU NAUCZYCIELA W PRZEDSZKOLU DWUJĘZYCZNYM
}

\begin{abstract}
Competences of the foreign language teacher in the immersive preschool. Preparing students for teaching in the bilingual preschool

This paper attempts to describe the competences of the preschool teacher. Focus is placed on communicative competences both in the pedagogical dimension, as well as in the in L2. The next point of the paper is to address the following question: how are foreign language teacher trainees prepared for work as L2-teachers in immersive preschools? The conclusions are made on the basis of a 150-hour observation which was conducted in an immersive Polish-German preschool in Poznań.
\end{abstract}

\section{Wstęp}

Istnieje wiele definicji kompetencji oraz wiele ich typologii (por. Strykowski, Strykowska i Pielachowski, 2003). Chcąc uniknąć pojęciowego chaosu w niniejszym artykule pragnę odnieść się do definicji i typologii kompetencji zaproponowanych przez Dylaka (1995), Pfeiffera (2001), Zawadzką (2004) i Doyé (2009) i na ich podłożu przedstawić kompetencje nauczyciela w przedszkolu dwujęzycznym polsko-niemieckim. Po części teoretycznej nastąpi opis badania empirycznego wraz z jego rezultatami. Wyprowadzenie wniosków dokonane zostało na bazie wnikliwej, liczącej co najmniej 150 godzin obserwacji bezpośredniej pracy nauczycieli w Dwujęzycznym Przedszkolu Polsko- 
Niemieckim „Ene due Rabe" ${ }^{1}$ w Poznaniu, jak i na podstawie prowadzonych przez autorkę zajęć z praktycznej nauki języka niemieckiego w Instytucie Lingwistyki Stosowanej UAM.

\section{Kompetencje współczesnego nauczyciela}

Dobry nauczyciel powinien dysponować wieloma kompetencjami definiowanymi przez Dylaka (1995: 37) jako „zbiór wiedzy, umiejętności, dyspozycji oraz postaw i wartości, niezbędnych dla skutecznej realizacji nałożonych zadań". W literaturze glottodydaktycznej pojawiają się także bardzo obszerne opisy kompetencji nauczyciela, także nauczyciela języków obcych (Zawadzka, 2004; Wysocka, 2003; Pfeiffer, 2001). Jak zauważa Zawadzka (2004), nowe sposoby nauczania wymagają od nauczyciela szerokiego spektrum umiejętności. Obok wiedzy i właściwego metodycznego przygotowania, osoba nauczająca musi posiadać znaczne kompetencje psychologiczno-pedagogiczne, interkulturowe, menedżerskie, doradcze, ewaluacyjne, ale przede wszystkim taka osoba powinna mieć odwagę do refleksji nad własnym działaniem i odwagę wprowadzenia zmian - nauczyciel musi być badaczem (Zawadzka, 2004).

Dylak (1995) wyodrębnia 3 rodzaje kompetencji zawodowych nauczyciela:

- kompetencje bazowe - sprawne działanie przynajmniej niektórych zmysłów, niezbędny poziom rozwoju intelektualnego i moralnego, wymagany poziom rozwoju społecznego, które pozwalają na porozumienie się z dziećmi, młodzieżą i współpracownikami,

- kompetencje konieczne - są to kompetencje, bez których osoba wykonująca zawód nauczyciela nie mogłaby pracować konstruktywnie tj. wypełniać przypisywanych danej szkole zadań edukacyjnych,

- pożądane - mogą znajdować się w profilu zawodowym nauczyciela, ale nie muszą, choć z pewnych względów ich posiadanie może być pomocne: np. gra na skrzypcach.

Szczegółowej analizie poddaje Dylak kompetencje konieczne, a wśród nich wyróżnia kompetencje interpretacyjne, autokreacyjne oraz realizacyjne. $W$ ramach kompetencji interpretacyjnych nauczyciel powinien dokonywać

\footnotetext{
${ }^{1}$ Przedszkole „Ene due Rabe” jest pierwszym w Poznaniu immersyjnym przedszkolem polsko-niemieckim. Utworzone ono zostało w kwietniu 2009 roku. Dzieci zanurzają się w język niemiecki podobnie, jak to się dzieje w rodzinie dwujęzycznej. Język niemiecki nie jest ograniczony do wybranych sytuacji. Towarzyszy on dzieciom we wszystkich aktywnościach przedszkolnych. Każdą grupą przedszkolną opiekują się dwie nauczycielki. Jedna porozumiewa się z dziećmi wyłącznie w języku niemieckim, a druga wyłącznie w języku polskim. Proces uczenia się języka niemieckiego jest ewaluowany.
} 
nieustannej krytycznej interpretacji świata: powinien on być intelektualistą, człowiekiem poszukującym prawdy i wartości, osobą nieustannie poddającą rozumnej krytyce swą wiedzę, swe działania oraz przedstawiane mu propozycje. Do kompetencji koniecznych należą także kompetencje autokreacyjne tzn. kompetencje tworzenia samego siebie, swej sylwetki zawodowej. Trzecią składową kompetencji koniecznych są kompetencje realizacyjne umożliwiające wykonywanie zadań edukacyjnych w szkole.

Zasadniczym „obiektem” bezpośrednich działań nauczyciela jest jednostka, grupa uczniów, klasa szkolna oraz cała społeczność szkolna.

Nauczyciel w klasie szkolnej ma przed sobq cały repertuar zachowań i czynności o różnym poziomie zorganizowania - od prostych reakcji do bardzo złożonych czynności metodycznych. Bazq dla tych najbardziej skomplikowanych czynności nauczyciela sa jednak jego zachowania ekspresyjne (E), często nie uświadamiane, a które już jako takie wywierajq określony wpływ na postawy i zachowania uczniów. Sq to zachowania niewerbalne, sposób mówienia, poruszania się po klasie itp. $Z$ tych to zachowań nauczyciel buduje swe czynności o charakterze socjotechnicznym (St), a więc: kierowanie klasq, wzbudzanie uwagi, organizowanie fizycznego środowiska itd. Takie działania sq zwykle składowymi technik, metod i czynności realizujacych zasady nauczania. Sq to najwyżej zorganizowane czynności metodyczne (M), jednak ich powodzenie w znacznym stopniu zależy od efektywności zachowań ekspresyjnych i socjotechnicznych (Dylak, 1995: 41).

Autor trafnie zauważa, iż w procesie kształcenia nauczycieli głównie zwraca się uwagę na czynności metodyczne (stosowanie metod, pisanie i realizacja konspektu, stosowanie form organizacyjnych, strategie lekcji, struktura wykładu), a zdecydowanie mniej uwagi poświęca się zachowaniom niewerbalnym, problemom emisji głosu, sposobowi poruszania się po klasie, technikom utrzymywania uwagi czy kierowania pracą grupy. Może to być jego zdaniem - podstawą trudności nauczycieli w realizacji niektórych metod nauczania. Dlatego w toku kształcenia właśnie ten ciąg czynności winien być wnikliwie trenowany (Dylak, 1995).

\subsection{Kompetencje nauczyciela języka obcego}

Kompetencjami nauczyciela języka obcego zajmowali się w swoich publikacjach m.in. Pfeiffer (2001), Zawadzka (2004), czy Wysocka (2003). Pfeiffer wyróżnia 5 komponentów kompetencji nauczyciela języka obcego jak kompetencja językowa, kompetencja metodyczna, kompetencja krajo- i kulturoznawcza, kompetencja pedagogiczna oraz kompetencja medialna. W ramach 
kompetencji językowej nauczyciel powinien posiąść wiedzę o tym przedmiocie i umiejętności z tym przedmiotem związane. Nauczyciel języków obcych musi opanować wiedzę gramatyczną o tym języku oraz umiejętności i sprawności językowych dla celów komunikacji (Pfeiffer, 2001: 194). W dalszej części autor słusznie zauważa, że w przypadku nauczyciela języka obcego niezwykle ważna jest także wiedza na temat gramatyki języka ojczystego, najlepiej w postaci kontrastywnej gramatyki dydaktycznej.

Kompetencja metodyczna w ujęciu Pfeiffera to umiejętność tworzenia i przeprowadzania efektywnych procesów glottodydaktycznych. Aby ją posiąść, nieodzowna jest:

- wiedza glottodydaktyczna obejmująca naukowe podstawy glottodydaktyki, jej przedmiotu, celów i metod badań;

- wiedza o związkach glottodydaktyki z dziedzinami pokrewnymi, zwłaszcza z psychodydaktyką i językoznawstwem;

- podstawy teorii akwizycji języka obcego;

- znajomość metod nauczania języka w rozwoju historycznym i aktualnego stanu dyskusji fachowej oraz

- znajomość metodyki nauczania języka.

Jednakże mistrzostwo metodyczne wykazywać będzie ten nauczyciel, który oprócz sprawności metodycznych sensu stricte posiada umiejętności komunikatywne obejmujące: umiejętność wprowadzania atmosfery językowej, umiejętność bycia komunikatywnym, umiejętność przystosowania się do lekcji w zależności od jej treści i charakteru, umiejętność kierowania uczącymi się, umiejętność wyrażania komunikatów przy pomocy mowy, mimiki, gestykulacji, umiejętność wyraźnego i emocjonalnego mówienia, umiejętność szybkiego ciągłego mówienia (Passow, 1984 za Pfeiffer, 2001). Tak więc także w opisie kompetencji nauczyciela języków obcych podkreśla się istotną wagę umiejętnych zachowań ekspresyjnych i socjotechnicznych. W dalszej części artykułu nastąpi odwołanie się do tych umiejętności komunikacyjnych, jako nieodzownych w pracy nauczyciela przedszkola bilingwalnego.

W ramach kompetencji krajo- i kulturoznawczej Pfeiffer akcentuje podstawową wytyczną, którą jest zasada relewantnej treści dla efektywnej komunikacji interkulturowej definiowana w następujący sposób: „wszystko, co dla skuteczności komunikacji jest niezbędne lub może ją zakłócić, powinno być poznane" ( Pfeiffer, 2001: 197).

Kolejną kompetencją nauczycielską jest kompetencja pedagogiczna. Autor podkreśla jej wagę nadmieniając, że w historii glottodydaktyki istniały czasy, w których nie doceniano znaczenia wychowania, a szczególnie wychowania interkulturowego. Ostatnią opisywaną przez autora kompetencją jest 
kompetencja medialna, w skład której wchodzi umiejętność sprawnej obsługi mediów oraz znajomość ich wielorakich funkcji dla efektywnego stosowania w procesie nauki języka. „Nauczyciel nie może nie umieć obsługiwać komputera, korzystać z Internetu i poczty elektronicznej. Taka niechętna mediom rezygnacyjna postawa wzbudzi podejrzenie uczniów o nieudolność, wygodnictwo, a nawet zacofanie dydaktyczne nauczyciela. Przed taką oceną trzeba się bronić" (Pfeiffer, 2001: 198).

Wyczerpującym opisem kompetencji nauczyciela języków obcych jest publikacja Zawadzkiej (2004). Autorka dokonała opisu kompetencji nauczyciela języków obcych poprzez role, które w procesie uczenia spełnia nauczyciel. Ze względu na bardzo wyczerpujący, poparty ogromną ilością badań naukowych opis koniecznych umiejętności nauczyciela, jak i ograniczenia edytorskie niniejszej publikacji nastąpi poniżej tylko przytoczenie najważniejszych ról spełnianych przez nauczyciela języków obcych, a zainteresowanego czytelnika kierujemy do dzieła. W ujęciu Zawadzkiej nauczyciel powinien być ekspertem w zakresie wiedzy przedmiotowej i kompetencji językowych, wiedzy i kompetencji psychologiczno-pedagogiczne oraz wiedzy i kompetencji metodycznych. Poza tymi funkcjami przed nauczycielem stoją zadania wychowawcy dzieci i młodzieży, pośrednika kulturowego, organizatora, moderatora i doradcy ewaluatora, innowatora, badacza i refleksyjnego praktyka. Już proste wyliczenie tych funkcji tworzy obraz fachowca o niezwykle szerokich umiejętnościach.

\subsection{Nauczyciel języka obcego w nauczaniu wczesnoszkolnym i przedszkolnym}

Opisując kompetencje nauczyciela nauczania wczesnoszkolnego i przedszkolnego pragnę zacząć od przypomnienia istotnego dokumentu dla nauczania języków obcych w niemieckim obszarze językowym, a mianowicie: Nürnberger Empfehlungen zum frühen Fremdsprachenlernen, który został opublikowany przez Goethe-Institut w 1996 roku, a w roku 2010 wznowiony i zaktualizowany. W tym dokumencie specjaliści z 22 krajów podjęli starania opisania procesu nauczania języków obcych małych dzieci ogniskując się na ich potrzebach i możliwościach. Oprócz takich kwestii jak: psychologiczne podłoże uczenia się języków obcych, koncepcje uczenia małych dzieci, potrzeby dzieci, prawa dzieci, treści uczenia, ocenianie, autorzy formułują postulaty wobec nauczycieli uczących małe dzieci. Na wstępie zaznaczają oni, że w nauczaniu wczesnoszkolnym nauczyciel spełnia kluczową rolę i jest najważniejszym autorytetem dla dziecka. Czym lepiej będzie on wykształcony w kwestii stawianych wobec niego specyficznych i różnorodnych zadań, tym bardziej efektywny będzie proces uczenia się dziecka. Uczenie zachodzi w systemie poznawczym dziecka, ale nauczyciel jest decydującym warunkiem tego procesu (Bleyhl, 2000: 29). 
W aspekcie znajomości języka obcego Nürnberger Empfehlungen zum frühen Fremdsprachenlernen stawiają nauczycielowi na poziomie wczesnoszkolnym bardzo wysokie wymagania: nauczyciele nauczania przedszkolnego i wczesnoszkolnego powinni więc dysponować solidną znajomością języka obcego, a szczególnie jego wariantem używanym w komunikacji z małymi dziećmi. Repertuar językowy nauczyciela powinien być na tyle wystarczający, aby mógł on podejmować ważne tematy, reagować stosownie do sytuacji, stosować bogate środki językowe oraz reagować adekwatnie w wymiarze emocjonalnym.

Niezwykle ważna jest jedna ze składowych umiejętności językowych nauczyciela, jaką jest kompetencja fonetyczna. Badania wykazują, że mimo stosowania bogatych środków audiowizualnych jako źródła inputu, dzieci przejmują wymowę swojego nauczyciela (Sambanis, 2007: 71-72). Taką sytuację można uzasadnić społeczno-pragmatyczną teorią uczenia się słów Tomasello, który pisze: „społeczno-konwencjonalna natura symboli językowych oznacza, że dzieci mogą się ich nauczyć tylko w interakcji z innymi osobami. To zaś, że funkcją symboli jest manipulowanie uwagą innych, znaczy, że dziecko może się nauczyć ich znaczenia komunikacyjnego, tylko wchodząc $w$ intersubiektywny stan podzielenia uwagi z dorosłym użytkownikiem języka, co powoduje, że zdolność do podzielenia z kimś uwagi staje się niezbędną podstawą do przyswajania symboli językowych i posługiwania się nimi" (Tomasello w Bokus, Shugar, 2007: 218). Umiejętności komunikacyjne nauczycieli nauczania wczesnoszkolnego to konglomerat sprawności językowej z umiejętnością skierowania uwagi w stronę dziecka. W ten sposób kompetencje językowe nauczyciela nieodłącznie łączą się z kompetencjami pedagogicznymi, niezwykle ważnymi w pracy z małymi dziećmi.

Praca z małymi dziećmi wymaga dużej gruntownej wiedzy pedagogiczno-psychologicznej dotyczącej rozwoju tego etapu obejmującego sylwetkę rozwojową dziecka, poznania podstawowych form aktywności dziecka, dysharmonii i zaburzeń rozwojowych, aspektów związanych z socjalizacją dziecka w społeczeństwie itd. Szerokie spektrum tych aspektów powoduje, że także umiejętności nauczyciela nauczania wczesnoszkolnego powinny być bardzo obszerne (zob. Andrzejewska, 2009). Do podstawowych składowych kompetencji pedagogicznej nauczyciela małych dzieci można zaliczyć: umiejętność oceny rozwoju psycho-społecznego dziecka, umiejętność diagnozowania problemowych zachowań uczniów i ich rozwiązywania, umiejętność diagnozowania środowiska społeczno-wychowawczego dziecka, umiejętność utrzymania pozytywnej motywacji uczniów do rozwoju. W ramach tych kompetencji należy szczególnie podkreślić komponent obejmujący umiejętność nauczyciela nawiązywania harmonijnej komunikacji z wszystkimi podmiotami związanymi ze szkołą: dziećmi, rodzicami, nauczycielami oraz innymi profesjonalistami (np. 
pracownikami poradni opiekuńczo-wychowawczych). Omawiając kompetencje współczesnego nauczyciela edukacji elementarnej nie wolno zapomnieć także o kompetencji interkulturowej, gdyż do zadań nauczyciela należy przybliżenie nie tylko języka, ale i kultury narodu, którego język dziecko poznaje.

\section{Wymagania stawiane nauczycielowi w przedszkolu immersyjnym - wybrane aspekty}

Metoda immersji w żadnej mierze nie jest metodą innowacyjną. Naukowe podstawy tej metody zostały opracowane w latach sześćdziesiątych w Kanadzie (Genesee, 1996), jednakże podobny sposób uczenia dzieci zaobserwować można dużo wcześniej na dworach, czy w bogatych domach, gdzie kształcenie dzieci powierzane było nauczycielkom (bonom) sprowadzanym z zagranicy. Metoda immersji polega na zastosowaniu języka obcego do przekazywania (uczenia) treści przedmiotowych. Język obcy służy jako „wehikuł” do transportu treści, a wybór środków językowych zależy od każdorazowej tematyki (Burmeister, 2006). Osoba ucząca się wystawiana jest na tak długą ekspozycję na język w warunkach przedszkolnych czy szkolnych, aż dojdzie w jej umyśle do rozpracowania kodu językowego na wszystkich poziomach językowych takich jak: poziom fonologii, morfologii, składni i użycia języka. Wg Wode (2006) musi być to okres co najmniej 6-7 lat. Na gruncie niemieckim w ramach nauczania wczesnoszkolnego metodę immersji wprowadzał zespół naukowców skupionych wokół dwujęzycznego przedszkola i szkoły im. Clausa Rixena w Altenholz k/Kilonii (Wode, 2006, Wode, 2009, Kersten 2005).

Metoda immersji (zanurzenia) w język obcy wzorowana jest na naturalnej akwizycji językowej. Dziecko wchodzi w świat języka obcego od pierwszych minut swojego pobytu w przedszkolu, w którym stosowana jest zasada one person - one language, co oznacza, że jedna z nauczycielek komunikuje się z dziećmi w języku ojczystym, a druga w języku obcym. Taka rzeczywistość stwarza dziecku możliwość wielogodzinnej ekspozycji na język obcy. Badania Wode (2009) wykazują, że w czasie trzyletniego pobytu w przedszkolu dzieci opanowuję sztukę rozumienia komunikatów w języku obcym, natomiast eksplozja produktywnych umiejętności językowych następuje pod koniec pierwszej klasy dwujęzycznej szkoły podstawowej.

W powyższych rozdziałach niniejszego artykułu nastąpiło naświetlenie szerokiej palety kompetencji nauczyciela języka obcego. Niniejszym pragnę przybliżyć kompetencje zawodowe nauczyciela w dwujęzycznym immersyj- 
nym $^{2}$ przedszkolu polsko-niemieckim oraz udzielić odpowiedzi na pytanie, czy studia neofilologiczne w dostateczny sposób przygotowują absolwentów do wykonywania tego zawodu.

Kwalifikacje do wykonywania zawodu nauczyciela w przedszkolu dwujęzycznym posiada absolwent studiów specjalności edukacja elementarna lub innego kierunku nauczycielskiego po ukończeniu studiów podyplomowych edukacja elementarna. Dodatkowo osoba taka powinna biegle władać językiem niemieckim, co oznacza, że powinien to być rodzimy użytkownik języka (Wode, 2006) lub osoba o kompetencji bliskiej rodzimemu użytkownikowi języka (Doyé, 2009). Z powyższego wynika, że absolwent neofilologii lub lingwistyki stosowanej może wykonywać zawód nauczyciela tylko po uzupełnieniu swojego wykształcenia o studia podyplomowe w ramach specjalności edukacja elementarna. Wydaje się jednak, że w sytuacji rozwinięcia szkolnictwa bilingwalnego na etapie przedszkolnym i wczesnoszkolnym, to właśnie absolwenci studiów neofilologicznych zasilą szeregi kadry nauczycieli przedszkolnych, gdyż uzupełnienie kwalifikacji pedagogiczno-dydaktycznych tej grupy jest związane ze zdecydowanie mniejszym nakładem pracy, niż zdobycie kompetencji obcojęzycznej przez absolwentów specjalności edukacja elementarna.

\section{Badanie empiryczne}

Badanie miało postać obserwacji jawnej, gdyż nauczyciele przedszkola „Ene due Rabe" wiedzą, że na terenie placówki przeprowadzane są badania zmierzające do kompleksowej oceny metody immersji. Badanie można także zaliczyć do obserwacji niekontrolowanej, to znaczy w trakcie badania nie użyto specjalnie skonstruowanych narzędzi badawczych. Jednakże była to obserwacja planowana zgodna z postawionymi celami. Badacz wyławiał z otaczającej go rzeczywistości dane i zapisywał je w dzienniku oraz gromadził materiał do oceny kompetencji językowej potrzebnej w czasie jego wykorzystania. Do oceny kompetencji językowej nauczyciela badacz zastosował także tzw. obserwację z wysokim stopniem uczestnictwa. Było to w sytuacjach, gdy przejmował on opiekę nad dziećmi (pomoc w czynnościach regulujących codzienny plan dnia, jak na przykład ubieranie się dzieci przed wyjściem na plac zabaw) oraz wykonywał z nimi zadania dydaktyczne np. przedstawienie krótkiej formy teatralnej z użyciem pacynek czy pomoc przy zajęciach plastycznych. Analizie

\footnotetext{
${ }^{2}$ Podkreślenie immersyjnym wynika z faktu, że w Polsce wiele przedszkoli nazywa się przedszkolami dwujęzycznymi, jednakże proponowany w nich model różni się od modelu immersyjnego. W powyższych przedszkolach proponowane są np. wydzielone lekcje z języka obcego w różnym wymiarze np. 1 godzina lekcyjna na dzień.
} 
poddano także program przedmiotu praktyczna nauka języka niemieckiego realizowanego w Instytucie Lingwistyki Stosowanej UAM w Poznaniu.

\subsection{Cel badania}

Celem badania była odpowiedź na następujące pytania:

- Jakimi kompetencjami powinien dysponować nauczyciel pracujący w przedszkolu immersyjnym polsko-niemieckim?

Ponieważ kompetencje nauczyciela są bardzo rozległym obszarem badawczym, badaniu poddano tylko kompetencję komunikacyjną nauczyciela w wymiarze nawiązywania interakcji, jak i kompetencję nauczyciela w zakresie języka obcego.

- Czy studia neofilologiczne lub na kierunku lingwistyka stosowana umożliwiają uzyskanie pełnej kompetencji w języku obcym potrzebnej do wykonywania zawodu nauczyciela języka obcego w przedszkolu immersyjnym?

\subsection{Osoby objęte badaniem}

W przedszkolu „Ene due Rabe” pracują dwie nauczycielki nauczania wczesnoszkolnego komunikujące się z dziećmi wyłącznie w języku niemieckim. Jedna z tych osób jest rodzimym użytkownikiem języka, druga posiada dobrą kompetencję językową, pogłębioną w czasie pracy w przedszkolu w Niemczech. Obie nauczycielki znają język odnoszący się do świata dzieci. W sytuacjach uczestniczących obiektem obserwacji był także sam badacz, absolwent filologii germańskiej - osoba znająca język niemiecki w stopniu dobrym, jednakże bez wnikliwej znajomości rejestru językowego dziecka. Osobami objętymi badaniem byli także studenci II roku lingwistyki stosowanej, z którymi autorka przeprowadza zajęcia z praktycznej nauki języka niemieckiego.

\subsection{Wnioski z badania empirycznego}

Kompetencja komunikacyjna nauczyciela w wymiarze pedagogicznym

Pierwszą, poddaną rozważaniu składową kompetencji nauczycielskich jest już wielokrotnie wspominana w tym artykule - kompetencja komunikacyjna w wymiarze nawiązywania interakcji z poszczególnymi dziećmi i całą grupą. Badanie wykazuje, że nauczyciel porozumiewający się z dziećmi w języku obcym musi posiadać ponadprzeciętne umiejętności w nawiązywaniu i pod- 
trzymywaniu interakcji z dziećmi. Komponentami powyższej kompetencji są następujące elementy: otwartość, szczerość, empatia, bogata w komunikaty mowa ciała, cierpliwość, umiejętność skupienia uwagi na sobie, jasna struktura aktywności przeprowadzanych z przedszkolakami (np. klarowne sygnalizowanie początku i końca aktywności), umiejętność rozpoznania potrzeb dziecka i nieforsowania swoich aktywności w sytuacji, gdy dziecko nie współpracuje, umiejętność włączenia dziecka w pracę grupy, znajomość technik organizujących pracę grupy np. rytuałów codzienności, technik formowania koła (takie ustawienie daje możliwość patrzenia na nauczyciela i eksponaty oraz usłyszenia swoich koleżanek i kolegów), umiejętność włączenia w pracę grupy dzieci z problemami wychowawczymi czy dysfunkcjami. Należy podkreślać, że w pracy nauczyciela dochodzi zawsze do integracji kompetencji, więc każda podgrupa tych sprawności powinna być na tyle wykształcona, by w kontakcie z dziećmi braki w zakresie kompetencji obcojęzycznej nie zdominowały uwagi nauczyciela.

\section{Przygotowanie studentów w zakresie kompetencji językowej}

Komunikacja z małymi dziećmi w języku obcym rodzi pewne problemy. Podstawowe trudności językowe w komunikacji z dziećmi wynikają z aspektu treści tematycznych świata dzieci, które zdecydowanie różnią się od treści tematycznych świata dorosłych. Ta odrębność dziecięcego świata implikuje trudności językowe związane z zasobami leksykalnym. Porównanie treści tematycznych przedmiotu praktyczna nauka języka niemieckiego z treściami tekstów tworzonych lub odtwarzanych (literatura dziecięca) w kontakcie z dziećmi, pozwala na wyciągnięcie wniosku, że studenci kierunków neofilologicznych nie posiadają możliwości (chyba, że spędzili dłuższy czas za granicą pracując jako opiekun/ka małych dzieci) poznania repertuaru środków leksykalnych, potrzebnych na stosowne reagowanie w bezpośredniej komunikacji z dziećmi (np. zamek mi się zaciął w kurtce, wyjmij tę łopatkę z błota).

Oprócz znajomości języka codziennej komunikacji, kontakty z dziećmi wymagają także bardzo dobrej znajomości fachowego słownictwa. Niezwykłym upodobaniem dzieci cieszą się tak zwane Wimmelbücher. Istotą tych książek są bogato ilustrowane strony, na których widać dziesiątki postaci wykonujących najrozmaitsze czynności w różnych miejscach/kontekstach lub dziesiątki różnych sytuacji. Dzieci uwielbiają wpatrywać się $w$ te bardzo szczegółowe obrazki i rozmawiać na ich temat.

Przykładem innej sytuacji wymagającej dobrego opanowania języka obcego są prośby dzieci o przeczytanie względnie porozmawianie na temat treści różnych książeczek przyniesionych z domu. Nauczyciel komunikujący 
się z dziećmi w języku niemieckim powinien w takiej sytuacji szybko zorientować się $w$ treści książki i podjąć rozmowę na temat interesujący dziecko. Współczesne książeczki dla dzieci zawierają jednakże słownictwo fachowe czy rzadko stosowane. Jako przykład niech posłuży autentyczna sytuacja, w której jeden z przedszkolaków poprosił o rozmowę na temat książki o samolotach. $W$ tej sytuacji nieodzowna była znajomość ekwiwalentów niemieckich słów: jednopłatowiec, dwupłatowiec, myśliwiec bombardujq̨cy, samolot z napędem rakietowym, samolot załogowy, bezzałogowy. W tym miejscu należy zauważyć, że polski rodzic $w$ rozmowie ze swoim dzieckiem z pewnością użyłby takiego słownictwa, więc chcąc zapewnić optymalne warunki do poznawania języka obcego metodą immersji, także i nauczyciel przedszkolny powinien umieć sprostać powyższym wyzwaniom językowym.

Inne działy tematyczne wymagające pogłębienia kompetencji językowej to: świat przyrody (np. rozwój motyla, dlaczego świetliki świecą, jak powstaje miód) czy świat zabaw chłopięcych (plac budowy, środki transportu, kosmos).

Do bardzo istotnych trudności językowych, które może napotkać nauczyciel pracujący metodą immersji, należy zaliczyć także brak umiejętności działania językowego w sytuacjach nacechowanych kulturowo takich jak np. jak wybrać członków drużyny do jakichś zawodów, czy jak pocieszyć w języku obcym trzyletnie dziecko w trudnej dla niego sytuacji emocjonalnej (Wode, 2006). Klasyczne tematy z realio- i kulturoznawstwa jak: system szkolnictwa, turystyczne atrakcje niemieckiego obszaru językowego, znani przedstawiciele świata sztuki są z pewnością niezbędnymi treściami programowymi studiów neofilologicznych, jednakże nie współgrają one z potrzebami placówek immersyjnych na poziomie przedszkolnym i wczesnoszkolnym. Z powyższego opisu wynika, że studenci neofilologii muszą być przygotowani na ciągłe pogłębianie swojej kompetencji językowej. Opisane powyżej przykłady nie są jednostkowe, lecz dotyczą codzienności przedszkola.

Język stosowany przez nauczycieli przedszkola charakteryzuje się następującymi cechami: prosta budowa zdań, stosunkowo dużo zdań w trybie rozkazującym, dużo zdań w trybie pytającym, dużo powtórzeń zdań, trochę wolniejsze tempo mówienia, klarowna segmentacja słów i sylab, dużo rzeczowników, mały stopień abstrakcji słów, język odnosi się do najbliższego środowiska dziecka. Należy jednakże podkreślić, że język nauczyciela nie powinien być ani zbyt uproszczony, ani infantylny. Wstępna analiza cech języka nie wskazuje na jego specjalną trudność, natomiast przy dokładnym przyjrzeniu się pojawiają się fenomeny, które pozwalają wyciągnąć wniosek, że także student kierunku neofilologicznego może mieć duże trudności w kształtowaniu komunikacji przebiegającej w języku o powyższych cechach. Biorąc pod uwagę cechy strukturalne napotykamy na często stosowany w świecie 
szkoły czy przedszkola tryb rozkazujący liczby mnogiej. Jak wykazują obserwacje, studenci filologii germańskiej posiadają duże niedobory w prawidłowym użyciu tej struktury. W bezpośredniej komunikacji ze studentami nauczyciele akademiccy stosują często formę grzecznościową (Lesen Sie bitte Ihr Beispiel!), która to forma należy do najprostszych struktur przy odmianie czasownika (versus Lies bitte dein Beispiel - I.poj. czy Lest bitte euer Beispiel I.mn.). Tak więc studenci nie posiadają zbyt wielu możliwości osłuchania się z trybem rozkazującym i zinterioryzowania jego form w bezpośrednim użyciu.

Kolejnym problemem studentów, związanym z użyciem struktur językowych jest odmiana rzeczowników i przymiotników. Duże tempo i naturalność sytuacji komunikacyjnych wymagają szybkiego, ale jednocześnie prawidłowego stosowania cech deklinacji rzeczowników i przymiotników. Tak więc, również w tym obszarze studenci powinni pogłębiać swoją kompetencję językową.

\section{Wnioski}

Jak pokazują badania o charakterze teoretycznym oraz praktycznym, praca w przedszkolu immersyjnym wymaga od nauczyciela niezwykle wielostronnych umiejętności. Jak zauważa Dylak (1995), podstawą wszystkich umiejętności nauczyciela są jego kompetencje komunikacyjne. W przedszkolu immersyjnym, w którym kontekst sytuacyjny jest tworzony w języku obcym, właściwe umiejętności ekspresyjne nauczyciela są bazą do nawiązania kontaktu z małym dzieckiem, dlatego powinny być one opanowane przez nauczyciela w stopniu maksymalnym. Wydaje się, że studia o specjalności glottodydaktycznej zbyt mało uwagi poświęcają temu nader ważnemu zagadnieniu. $Z$ uwagi na drugi podstawowy cel, jaki realizuje przedszkole immersyjne, to znaczy naukę języka obcego, także wymagania stawiane nauczycielowi przedszkolnemu w zakresie znajomości języka obcego są niezwykle wysokie. Studia neofilologiczne stanowią więc tylko pierwszy krok w zdobywaniu kompetencji potrzebnych do pracy w przedszkolu. Absolwent lingwistyki stosowanej/neofilologii pragnący pracować z małymi dziećmi w przedszkolu dwujęzycznym, będzie musiał podjąć dodatkową pracę nad swoją kompetencją językową, by móc realizować sytuacje komunikacyjne w kontekstach specyficznych dla małego dziecka.

\section{BIBLIOGRAFIA}

Andrzejewska, E. 2009. „Anforderungen an Lehrer“ w Hallo Deutschlehrer. Z.29. 10-13. Bleyhl, W. 2000. Fremdsprachen in der Grundschule. Grundlagen und Praxisbeispiele. Hannover: Schroedel Verlag. 
Kompetencje nauczyciela języka obcego w przedszkolu immersyjnym...

Bokus, B; Shugar, G.W. (red.) 2007. Psychologia języka dziecka. Osiqgnnięcia, nowe perspektywy. Gdańsk: GWP.

Burmeister, P. 2006. „Immersion und Sprachunterricht im Vergleich“. [w:] Pienemann, M.; Keßler, J.U. i Roos, E. (red.). Englischerwerb in der Grundschule. Ein Studien- und Arbeitsbuch. Paderborn: Ferdinand Schöningh. 97-216.

Doyé, P. 2009. Didaktik der bilingualen Vorschulerziehung. Dargestellt am Beispiel der vorschulischen Einrichtungen in Berlin und Wolfsburg. Tübingen: Gunter Narr Verlag.

Dylak,S. 1995. Wizualizacja w kształceniu nauczycieli. Poznań: Wydawnictwo Naukowe UAM.

Genesee, F.1996. „Immersion in Kanada - drei pädagogische Lektionen“ . [w:] Kubanek-German, A. (red.) . Immersion Fremdsprachenlernen Primarbereich. München: Goethe-Institut. 37-52.

Kersten, K. 2005. „Bilinguale Kindergärten und Grundschulen: Wissenschaft und Praxis im Kieler Immersionsprojekt". [w:] Baron, P. ( red.). Bilingualität im Kindergarten und in der Primarstufe. Bessere Zukunftschancen für unsere Kinder. Opole: Niemieckie Towarzystwo Oświatowe. 22-33.

Nürnberger Empfehlungen zum frühen Fremdsprachenlernen. Neubearbeitung. 2010. München: Goethe-Institut.

Pfeiffer, W. 2001. Nauka języków obcych, Od praktyki do praktyki. Poznań: Wagros.

Sambanis, M. 2007. Sprache aus Handeln. Englisch und Französisch in der Grundschule. Landau: Verlag Empirische Pädagogik.

Strykowski, W.; Strykowska, J.; Pielachowski, J. 2003. Kompetencje nauczyciela szkoły współczesnej. Poznań: Wydawnictwo eMPi ${ }^{2}$.

Tomasello, M. 2007. „Społeczno-pragmatyczna teoria uczenia się słów”. [w:] Bokus, B; Shugar, G.W. (red.). Psychologia języka dziecka. Osiągnięcia, nowe perspektywy. Gdańsk: GWP. 211-224.

Wode, H. 2006. „Mehrsprachigkeit durch immersive KiTas. Eine überzeugende Methode zum nachhaltigen Fremdsprachenerwerb“. [w:] Zukunfts-Handbuch Kindertageseinrichtungen: Qualitätsmanagement für Träger, Leitung, Team. Regensburg/Berlin: Walhalla Fachverlag.

Wode, H. 2009. Frühes Fremdsprachenlernen in bilingualen Kindergärten und Grundschulen. Braunschweig: Bildungshaus Schulbuchverlage.

Wysocka, M. 2003. Profesjonalizm w nauczaniu języków obcych. Katowice: Wydawnictwo Uniwersytetu Śląskiego.

Zawadzka, E. 2004. Nauczyciele języków obcych w dobie przemian. Kraków: Oficyna Wydawnicza „Impuls”. 